\title{
Front Matter: Volume 9994
}

, "Front Matter: Volume 9994," Proc. SPIE 9994, Optical Materials and Biomaterials in Security and Defence Systems Technology XIII, 999401 (5 December 2016); doi: 10.1117/12.2263719

SPIE. Event: SPIE Security + Defence, 2016, Edinburgh, United Kingdom 


\title{
Optical Materials and Biomaterials in Security and Defence Systems Technology XIII
}

\author{
Roberto Zamboni \\ François Kajzar \\ Attila A. Szep \\ Katarzyna Matczyszyn \\ Editors
}

\section{8-29 September 2016 \\ Edinburgh, United Kingdom}

Sponsored by

SPIE

Cooperating Organisations

Innovation Centre for Sensor and Imaging Systems (United Kingdom)

ADS Scotland (United Kingdom)

The Knowledge Transfer Network (United Kingdom)

Visit Scotland (United Kingdom)

European Regional Development Fund (Belgium)

Technology Scotland (United Kingdom)

Published by

SPIE 
The papers in this volume were part of the technical conference cited on the cover and title page. Papers were selected and subject to review by the editors and conference program committee. Some conference presentations may not be available for publication. Additional papers and presentation recordings may be available online in the SPIE Digital Library at SPIEDigitallibrary.org.

The papers reflect the work and thoughts of the authors and are published herein as submitted. The publisher is not responsible for the validity of the information or for any outcomes resulting from reliance thereon.

Please use the following format to cite material from these proceedings:

Author(s), "Title of Paper," in Optical Materials and Biomaterials in Security and Defence Systems Technology XIII, edited by Roberto Zamboni, François Kajzar, Attila A. Szep, Katarzyna Matczyszyn, Proceedings of SPIE Vol. 9994 (SPIE, Bellingham, WA, 2016) Six-digit Article CID Number.

ISSN: 0277-786X

ISSN: 1996-756X (electronic)

ISBN: 9781510603929

ISBN: 9781510603936 (electronic)

Published by

SPIE

P.O. Box 10, Bellingham, Washington 98227-0010 USA

Telephone +1 3606763290 (Pacific Time) · Fax +1 3606471445

SPIE.org

Copyright @ 2016, Society of Photo-Optical Instrumentation Engineers.

Copying of material in this book for internal or personal use, or for the internal or personal use of specific clients, beyond the fair use provisions granted by the U.S. Copyright Law is authorized by SPIE subject to payment of copying fees. The Transactional Reporting Service base fee for this volume is $\$ 18.00$ per article (or portion thereof), which should be paid directly to the Copyright Clearance Center (CCC), 222 Rosewood Drive, Danvers, MA 01923. Payment may also be made electronically through CCC Online at copyright.com. Other copying for republication, resale, advertising or promotion, or any form of systematic or multiple reproduction of any material in this book is prohibited except with permission in writing from the publisher. The CCC fee code is 0277-786X/16/\$18.00.

Printed in the United States of America.

Publication of record for individual papers is online in the SPIE Digital Library.

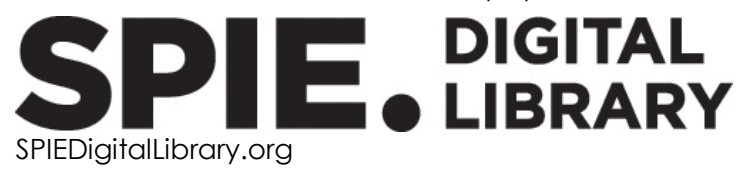

Paper Numbering: Proceedings of SPIE follow an e-First publication model. A unique citation identifier (CID) number is assigned to each article at the time of publication. Utilization of CIDs allows articles to be fully citable as soon as they are published online, and connects the same identifier to all online and print versions of the publication. SPIE uses a six-digit CID article numbering system structured as follows:

- The first four digits correspond to the SPIE volume number.

- The last two digits indicate publication order within the volume using a Base 36 numbering system employing both numerals and letters. These two-number sets start with 00, 01, 02, 03, 04, 05, $06,07,08,09,0 A, O B \ldots$. OZ, followed by $10-1 Z, 20-2 Z$, etc. The CID Number appears on each page of the manuscript. 


\title{
Contents
}

\author{
$\checkmark$ Authors \\ vii Conference Committee
}

ORGANIC ELECTRONICS AND SIGNAL PROCESSING

999404 Materials for near-IR light modulation (Invited Paper) [9994-3]

HYBRID MATERIALS AND APPLICATIONS

$999401 \quad$ Nitrogen vacancies in the GaN/AIN heterointerface [9994-19]

POSTER SESSION

9994 ON FBG sensor of breathing encapsulated into polydimethylsiloxane [9994-8]

999400 Frequency analysis of the new prototype of the security window sensor [9994-24]

9994 OP Influence of PDMS encapsulation on the sensitivity and frequency range of fiber-optic interferometer [9994-25] 
Proc. of SPIE Vol. $9994999401-4$

Downloaded From: https://www.spiedigitallibrary.org/conference-proceedings-of-spie on 26 Apr 2023 Terms of Use: https://www.spiedigitallibrary.org/terms-of-use 


\section{Authors}

Numbers in the index correspond to the last two digits of the six-digit citation identifier (CID) article numbering system used in Proceedings of SPIE. The first four digits reflect the volume number. Base 36 numbering is employed for the last two digits and indicates the order of articles within the volume. Numbers start with 00, 01, 02, 03, 04, 05, 06, 07, 08, 09, 0A, 0B...0Z, followed by 10-1Z, 20-2Z, etc.

Bednarek, Lukas, 00

Bezyazychnaya, Tatyana $\vee .$, ol

Fajkus, Marcel, ON, 0O, OP

Lebiadok, Yahor $\mathrm{V}$., 0 l

Nedoma, Jan, ON, 0O, OP

Novak, Martin, 00

Robertson, Neil, 04

Siska, Petr, ON

Vasinek, Vladimir, ON, OO, OP

Whyte, Alexander M., 04

Zhuravlev, Konstantin S., Ol

Proc. of SPIE Vol. $9994999401-5$ 
Proc. of SPIE Vol. $9994999401-6$

Downloaded From: https://www.spiedigitallibrary.org/conference-proceedings-of-spie on 26 Apr 2023 Terms of Use: https://www.spiedigitallibrary.org/terms-of-use 


\section{Conference Committee}

Symposium Chair

David H. Titterton, United Kingdom Defence Academy (United Kingdom)

Symposium Co-chair

Ric Schleijpen, TNO Defence, Security and Safety (Netherlands)

Karin Stein, Fraunhofer-Institut für Optronik, Systemtechnik und Bildauswertung (Germany)

Stuart S. Duncan, Leonardo-Finmeccanica (United Kingdom)

Conference Chairs

Roberto Zamboni, Istituto per la Sintesi Organica e la Fotoreattività (Italy)

François Kajzar, Politehnica University of Bucharest (Romania)

Attila A. Szep, Air Force Research Laboratory (United States)

Katarzyna Matczyszyn, Wroclaw University of Technology (Poland)

Conference Program Committee

Chantal Andraud, Ecole Normale Supérieure de Lyon (France)

André-Jean Attias, Université Pierre et Marie Curie (France)

Carrie M. Bartsch, Air Force Research Laboratory (United States)

Werner J. Blau, Trinity College Dublin (Ireland)

Fabrice Charra, Commissariat à l'Énergie Atomique (France)

Larry R. Dalton, University of Washington (United States)

Beata J. Derkowska, Torun University (Poland)

Manfred Eich, Technische University Hamburg-Harburg (Germany)

Patrick Feneyrou, Thales Research \& Technology (France)

Barrett Flake, European Office of Aerospace Research and

Development (United Kingdom)

James G. Grote, Air Force Research Laboratoy (United States)

Emily M. Heckman, Air Force Research Laboratory (United States)

Charles Y. C. Lee, Air Force Office of Scientific Research

(United States)

Antoni C. Mitus, Wroclaw University of Technology (Poland)

Jaroslaw Mysliwiec, Wroclaw University of Technology (Poland)

Robert L. Nelson, Air Force Research Laboratory (United States)

Yoshiko Okada-Shudo, The University of Electro-Communications (Japan) 
Fahima Ouchen, Air Force Research Laboratory (United States)

Agnieszka Pawlicka, Instituto de Química de São Carlos (Brazil) Ullrich Pietsch, Universität Siegen (Germany)

lleana Rau, Politehnica University of Bucharest (Romania)

Ifor D. W. Samuel, University of St. Andrews (United Kingdom)

Marina Saphiannikova Grenzer, Leibniz-Institut für Polymerforschung Dresdene e.V. (Germany)

Niyazi Serdar Sariciftci, Johannes Kepler Universität Linz (Austria)

Renato Seeber, Universitè degli Studi di Modena e Reggio Emilia (Italy)

Kenneth D. Singer, Case Western Reserve University (United States)

\section{Session Chairs}

1 Organic Electronics and Signal Processing

Attila Szep, Air Force Research Laboratory (United States)

2 Applications

Roberto Zamboni, Istituto per la Sintesi Organica e la Fotoreattività (Italy)

3 Materials

Katarzyna Matczyszyn, Wroclaw University of Science and Technology (Poland)

4 Light Emission

François Kajzar, Politehnica University of Bucharest (Romania)

5 Hybrid Materials and Applications

Yoshiko Okada-Shudo, The University of Electro-Communications (Japan)

6 Biomaterials and Applications

Kwang-Sup Lee, Hannam University (Korea, Republic of) 